\title{
Adoption of principle-based IFRS and intercompany comparability of operating performance
}

\author{
Protap Kumar Ghosh, Ranajit Kumar Bairagi and Abinash Mondal \\ Business Administration Discipline, Khulna University, \\ Khulna, Bangladesh
}

\begin{abstract}
Purpose - The study aims to investigate whether the adoption of IFRS could ensure ultimate intercompany comparability of operating performance in terms of uniformity in the application of accounting methods and reporting style.

Design/methodology/approach - Using content analysis on 125 annual financial statements of 25 companies from five industries listed on the Dhaka Stock Exchange in Bangladesh, this study reports that only the sole adoption and application of principle based IFRS cannot ensure ultimate intercompany comparability of financial reports.

Findings - The findings document that the adoption of IFRS cannot ensure the application of same accounting methods as well as way of presentations which is a precondition of greater comparability of operating performance of competitive firms. The methodological and reporting direction through local regulatory agencies alongside maximum compliance with principle based IFRS can enhance intercompany comparability of financial reports in the same industry.

Originality/value - This study tries to manifest that sole adoption cum implementation of IFRS could not ensure ultimate intercompany comparability of operating performance within the same industry and urges to conduct further research to find out the ways to do so.
\end{abstract}

Keywords Principle based IFRS, Consistency, Intercompany comparability, Content analysis

Paper type Research paper

\section{Introduction}

Why do retail investors ignore accounting information? Blankespoor et al. (2019) concluded that the cost of monitoring and acquiring accounting information demotivates retail investors using accounting disclosures in stock trading decisions. Although the cost of acquisition and processing of accounting information could avert traders using available accounting disclosures (Bhattacharya, 2001), sometimes they are reluctant to utilize all available information (Malmendier and Shanthikumar, 2007). In the hazy environment, users need to spend much time and efforts on acquisition, processing and analysis of accounting disclosures (Francis and Schipper, 1999; Ely and Waymire, 1999; Hope, 2003). Investors sometimes also depend on nonaccounting information while they doubt higher uncertainty on accounting disclosure (Amir and Lev, 1996). Financial statements having greater comparability enhance value relevance in stock trading and facilitate investors to gather and analyze information at a lower cost (De Franco et al., 2011; Kim et al., 2013). Sunder (2002) exposed that the financial reporting quality of firms depends to a greater extent on two essential variables, namely consistency of accounting methods and comparability of financial

(C) Protap Kumar Ghosh, Ranajit Kumar Bairagi and Abinash Mondal. Published in Asian Journal of Accounting Research. Published by Emerald Publishing Limited. This article is published under the Creative Commons Attribution (CC BY 4.0) licence. Anyone may reproduce, distribute, translate and create derivative works of this article (for both commercial and non-commercial purposes), subject to full attribution to the original publication and authors. The full terms of this licence may be seen at http:// creativecommons.org/licences/by/4.0/legalcode
Adoption of principle-based IFRS

Received 15 April 2020 Revised 25 May 2020 4 June 2020

Accepted 1 July 2020 
AJAR 5,2 reports. The greater comparability of accounting information by increasing the quality of financial reporting can reduce the cost of evaluating alternative investment opportunities (Barth, 2013).

Adoption and compliance with International Financial Reporting Standards (IFRS) and Generally Accepted Accounting Principles (GAAP) in a country theoretically enhances the quality of financial reporting as well as enlarges the uniform accounting practices across the world. Li et al. (2017) concluded that adoption of IFRS enhances the capability of accounting information to predict future earnings and cash flows. But Capkun et al. (2016) concluded that greater flexibility having unclear guidance of implementation in IFRS initiated increased earning management in financial reports. Donelson et al. (2012) concluded that the rulesbased accounting standards have less chance to litigation for malpractice because the rulesbased accounting standards require more detailed guidelines, scope expectations and significant volume of application guidance (Nelson, 2003; Schipper, 2003 and Di Piazza et al., 2006), which makes accounting standard more precise and minimizes the chance of applying professional judgments. While Schipper (2003) concluded principles-based accounting standards might enhance the companies' exposure to litigation. Harris and Muller (1999) examined the value relevance of financial reporting under IFRS and US GAAP and found that nonUS companies that employed IFRS in financial reporting with a reconciliation to US GAAP evidenced more value-relevant in the market. Barth et al. (2012) concluded value relevance and comparability of accounting reports were higher for the firms that adopted IFRS mandatorily than US GAAP-based accounting. Zarova et al. (2014) concluded that accounting harmonization aimed to set degrees of variation in accounting practices to reduce differences in financial reporting among different nations having different economic background. It is also claimed that IFRS has lost its overall international character and espoused country specific environments where it has been applied (Nobes and Parker, 2012). In Europe, Brüggemann et al. (2013) reported that the mandatory adoption of IFRS enhanced superior comparability of financial reporting at the international level but reduced it at the domestic economies.

Until 2012, Bangladesh adopted 29 IASs and 13 IFRSs but the quality of financial reporting is still claimed far behind to make it lucrative to its intended users. Although compliance with the prescribed principles-based IFRSs can enhance the comparability of financial reporting, two companies with thesame natureare not compelled to follow the same accounting methods for their accounting practices. Consequently, these methodological diversities theoretically distort intercompany comparability of operating performance presented through accounting reports. This study aims to investigate to what extent principles-based IFRSs can guarantee intercompany comparability of operating performance ensuring intracompany and intercompany consistency in the application of accounting methods in financial reporting. To execute our research goal, this paper is divided into five sections. In the introduction, the aim of this paper is disclosed. In the literature review section, the linkage between adoption of and compliance with IFRSs and quality of financial reports has been tried to establish and then it is turned to comparability of accounting reports. The methodology section articulates the ways how the aim of this paper is achieved. In the findings section, we have tried to show level of intracompany consistency in the application of accounting methods and then intercompany comparability of operating performance in terms of the application of same accounting methods in financial reporting. Finally, conclusion section summarizes our findings and limitation of this study.

This study finds that sole adoption of IFRS can not ensure intercompany comparability of operating performance of financial reports because of methodological diversities in financial reporting. And, the findings will stimulate stock traders to create continuous pressure on the reporting organizations as well as on the regulatory bodies to formulate favorable relevant policies and accounting guidelines to resolve this critical issue to facilitate investors in stock trading. 


\section{Literature review}

The literature shows each and every country has its own imposed specified rules, regulations and techniques in preparing financial reports (De Franco et al., 2011). However, the adoption and implementation of international accounting standards has been increasing day by day due to its impacts on improved quality of financial reporting. Peña and Franco (2017) concluded that the adopting IFRS in the UK and France reported significant improvement in quality of financial reporting in the UK but not in France. This is consistent with that of Kim et al. (2012) except that mandatory adoption of IFRS increased the complexity of audit work and the cost of audit fees. Lourenço et al. (2015) concluded that adoption of IFRS generally had a positive impact on quality financial reporting, the capital market, analysts' ability to predict, comparability and information usages; however, the intensity of these impacts were subject to some factors including country's enforcement level and nature of companies. Bassemir and Novotny-Farkas (2018) reported increased earning quality in the firms adopting IFRSs in Germany along with disclosing significantly more information in their financial reports and tending to voluntarily publish their financial reports on their corporate website. Turki et al. (2016) found improved information contents of earnings after the IFRS mandatory adoption and the improvement was reflected in reduced cost of capital as well as in error and dispersion of financial analysts' forecasting.

Jermakowicz (2004) concluded that adoption of IFRS in Belgium dramatically changed external reporting activities of the companies and increased the comparability and levels of transparency of financial reporting. Brochet et al. (2013) exposed that adoption of IFRS decreased information asymmetries and increased the firm-level comparability in financial reporting in the UK Wang (2011) also revealed that IFRS adoption increased cross-country information transfer by improving its comparability. The adoption of unified financial reporting standards should enhance superior comparability and transparency of financial reports and reduce information asymmetry among the stakeholders by improving information quality (Thorell and Whittington, 1994). The comparability of financial information of a firm with its industry peers helps retail investors better assess its competitive benefits or drawbacks for specific investments (Ozkan et al., 2012; Young and Zeng, 2015). In a study over 17 European countries, Yip and Young (2012) concluded that adoption of IFRS increased accounting comparability in terms of similarity of accounting practices, degree of information transfer and earning and book value reporting. The higher accounting comparability helps reduce information asymmetry and helps investors analyze firm-specific information to evaluate alternative investment opportunities (Peterson et al., 2015); increases the efficiency of capital allocation (Durnev et al., 2003, 2004); benefits both public debt markets and (Kim et al., 2013) private loan markets (Fang et al., 2016). Schiebel (2007) studied the value relevance of accounting information under IFRS and German GAAP and eventually concluded that German GAAP has more value relevance than IFRS.

The contrary evidence is also reported in the literature. For example, Ahmed et al. (2013) found declined quality of financial reporting due to mandatory adoption of IFRS in a country. As the coexistence of both IFRS and local accounting standards in a country adversely affects the comparability, local accounting standards need to be essentially adjusted to make them compatible with IFRSs (Callao et al., 2007). Lin et al. (2019) concluded that adoption of IFRS could not enhance the comparability of accounting information significantly. But Armstrong et al. (2010) concluded that the adoption of IFRS increased comparability and quality of financial reporting which ultimately materialized the investors' perceived net benefits in Europe. Some research studies revealed that adoption of IFRS enhanced value relevance of accounting information (Bartov et al., 2005; Harris and Muller, 1999; Horton and Serafeim, 2006), while others evidenced that the same could worsen value relevance (Lin and Chen, 2005; Schiebel, 2007).
Adoption of principle-based IFRS 
AJAR

5,2

344

The upper echelons theory articulated how individual factors and team practices affect the executive decision-making (Nielsen, 2010) and also mixtures theories like agency theory and positive accounting theory. A variety of theoretical viewpoints along with the upper echelons theory explained how the top management's demographic diversity influences financial reporting quality and discretionary accounting choices. The upper echelons theory identified six observable characteristics (age, functional background, other career experiences, formal education, socio-economic status and financial position) that contribute to the individual personal background or leadership experience that distinguishes each other (Hambrick and Mason, 1984), and the current accounting research also shows how managerial expertise and leadership role have important explanatory power for accounting choices and outcomes (Bamber et al., 2010; Ge et al., 2011). However, both positive and negative relationship of TMT demographic diversity with financial reporting quality are evident in the literature (Bamber et al., 2010; and Ge et al., 2011; Steccolini, 2004; Fawzi et al., 2001).

Watts and Zimmerman (1986) developed the positive accounting theory (PAT) to explain and predict firm's choices on accounting practices. The theory hypothesizes that accounting choices may be determined by managers who want to influence reported earnings and capital structure in imperfect markets. Watts and Zimmerman (1986) further noted that the companies having higher information asymmetry among managers and external investors are more conservative in financial reporting. This conservatism is also influenced by the managers' specific characteristics (CFOs) and GAAPs (Ge et al., 2011). The information asymmetry resulting from the agency theory can also describe the financial reporting quality (Jensen and Meckling, 1976). Sweeney (1994) exposed managerial motivation to adapt income increasing accounting policies to inflate reported net income of the firm.

The above literature studies expose that adoption of IFRS to a greater extent enhances the quality of financial reporting and overall comparability of financial reports but assurance for ultimate intercompany comparability of financial reports is in question. Furthermore, it also shows managerial discretion plays a significant role in financial reporting although the local rules and regulations limit the application of managerial discretion in this regard. So, the proposition of this study is adoption of IFRS and compliance with it could confirm intercompany comparability of operating performance of the reporting organizations by ensuring consistency in the application of similar accounting methods. In Bangladesh, the Company Act - 1994 mainly describes the basic requirement of the contents of financial statements. ICAB (Institute of Chartered Accountants of Bangladesh) plays the key role of adoption and implementation of IFRSs here. ICAB adopts IFRS with little modification and publishes it as BFRS (Bangladesh Financial Reporting Standards) The Company Act does not make it mandatory to comply with IFRSs but requires the financial statements to be audited by the member of ICAB. And, the members of ICAB ensure compliance with BFRS in financial reporting as per ICAB requirements [1]. This study is designed to investigate whether the adoption of principle based IFRS could ensure extreme intercompany comparability of operating performance of various companies ensuring the application of same accounting principles and methods from company to company within the same industry to make financial reports more lucrative to its intended users.

\section{Methodology}

This is a qualitative study and uses content analysis approach to achieve our research objective. No quantitative analysis is included in this paper. The content analysis is done on 125 annual financial statements extracted from 25 companies selected from five industries listed in the Dhaka Stock Exchange (DSE), Bangladesh, for five years from 2013 to 2017. Using a judgmental sampling technique including the market reputation and availability of information, five 
industries are initially selected from the DSE. The reason behind selecting Bangladesh as empirical setting is that Bangladesh is one of the fast growing economies in the world and accounting practices here is getting more importance day by day to disclose authentic financial performance of various companies to make it trust worthy to the users of accounting information. Bangladesh is now considered as the role model for other developing countries, and the findings of this study can help developing countries to upgrade their accounting practices. From each of the selected industries, five companies are selected resulting in 125 financial statements. The literature review results in five key variables, namely "Reporting period (RP) ", "method of depreciations (MODs)", "inventory valuation method (IVM)", "assets valuation method (AVM)" and "steps in reporting (SOP)".

\begin{tabular}{|c|c|}
\hline Variables & Description \\
\hline Reporting period: (RP) & $\begin{array}{l}\text { It represents period of time for which companies prepared their financial } \\
\text { reports }\end{array}$ \\
\hline $\begin{array}{l}\text { Method of deprecation: } \\
\text { (MOD) }\end{array}$ & It denotes the methods various companies use to depreciate their assets \\
\hline $\begin{array}{l}\text { Inventory valuation method: } \\
\text { (IVM) }\end{array}$ & $\begin{array}{l}\text { It signifies how the selected companies determine the value of their various } \\
\text { inventories }\end{array}$ \\
\hline $\begin{array}{l}\text { Assets valuation method: } \\
\text { (AVM) }\end{array}$ & $\begin{array}{l}\text { It represents how the selected companies present their assets on the balance } \\
\text { sheet except inventories }\end{array}$ \\
\hline Steps in presentation: (SOP) & $\begin{array}{l}\text { It represents various headings under which various financial and nonfinancial } \\
\text { items are presented }\end{array}$ \\
\hline
\end{tabular}

Adoption of principle-based IFRS

Focusing on five selected variables, our primary content analysis of collected financial statements generates five function tables. Then, based on the five function tables [2], we have prepared two summary tables. Summary Table 1 is prepared to check intracompany financial reporting consistency, whereas summary Table 2 is prepared to check intercompany comparability of financial reports. In preparing summary Table 1 , we use " $\sqrt{ }$ "and " $\times$ " to record intercompany consistency and inconsistency, respectively. Summary Table 2 reports intercompany comparison in the same RP among selected organizations under the same industry. To record similarities in selected five dimensions (such as RP MOD and so on) among the companies within the same industry, we use " $\sqrt{ }$ " otherwise " $\times$ ". Finally, we have presented the overall position regarding consistency and comparability of operating performance in corporate financial reporting in Bangladesh.

\section{Findings}

Bangladesh adopted 29 IASs and 13 IFRSs with some modifications until 2012. Every organization is compelled to follow "Bangladesh Accounting Standard" adopted from IASs and IFRS along with other local reporting guidelines in financial reporting. The function tables report that of all the statements, 121 statements are reported for annual basis; two statements are reported for six months and remaining two are reported for 18 months. For inventory valuation, various methods such as LC, WAC, FIFO, etc. are used by our sampled organizations. To depreciate their real assets, both the straight line (SL) and the diminishing balance (DB) methods are followed by selected companies. While presenting assets on balance sheet, most of the companies use historical cost. However, only one company uses market value for the same. Only few companies maintain similarities in various steps of presenting (SOP) relevant information in annual reports, but most of the organizations $(80 \%$ of total) are inconsistent in this regard. 


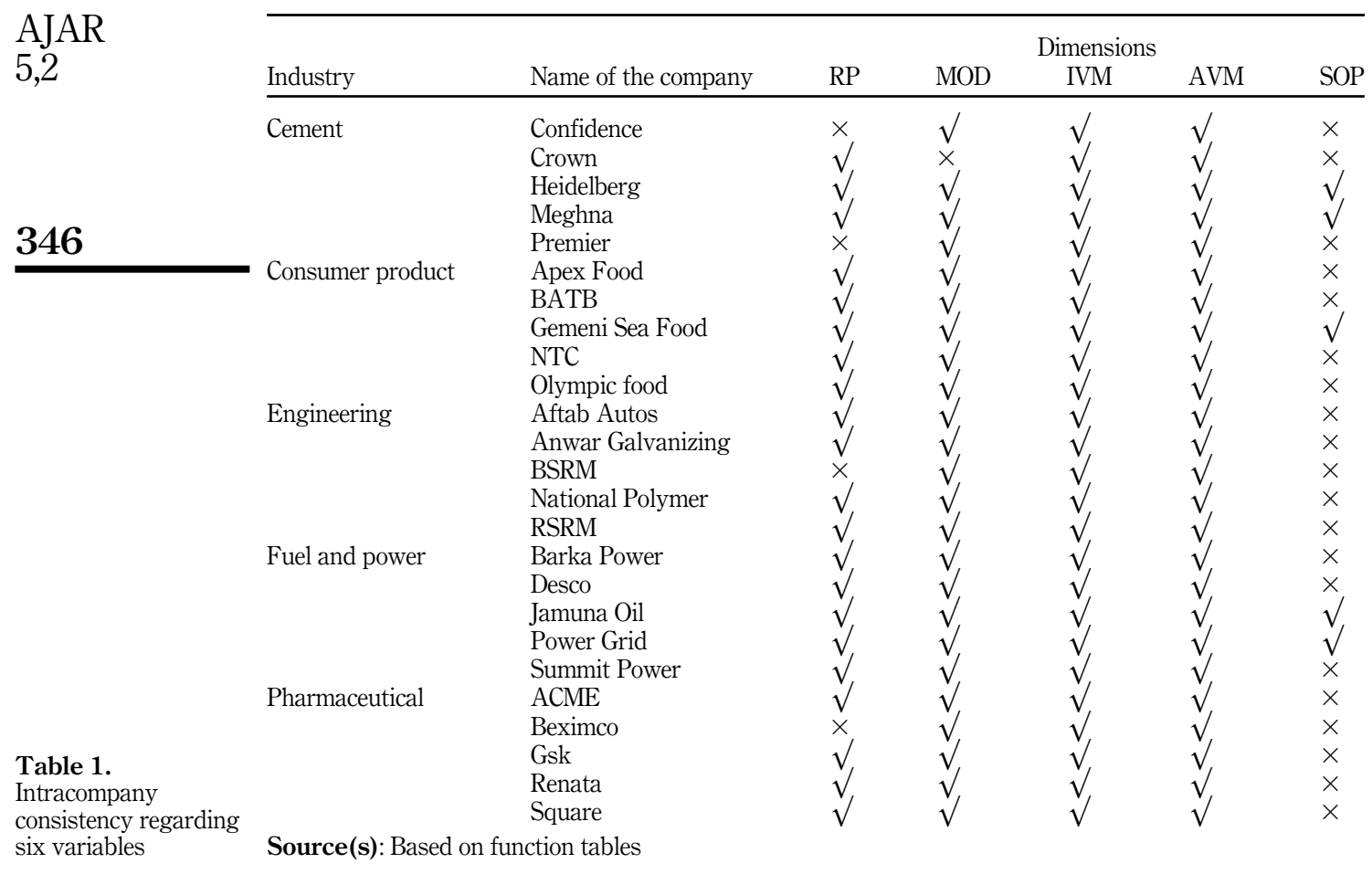

\subsection{Intracompany consistency in financial reporting}

Consistency in the application of various accounting methods is essential to avoid earning manipulation and to ensure intracompany comparability of financial reports time. Table 1 reports the overall status of intracompany periodic consistency in selected five dimensions. More specifically, in cement industry, two companies are inconsistent in reporting period, and one company is inconsistent in the method of depreciation. However, in terms of IVM and AVM, they are consistent, whereas three companies are inconsistent in terms of SOP. In consumer product industry, dimensions except SOP are consistent in implementation of corporate financial reporting and only Gememi Sea Food is consistent in SOP. In engineering industry, no company has shown consistency in the SOP in annual reports. For rest of the dimensions, all the companies are consistent except BSRM in reporting period.

In fuel and power industry, only three companies are inconsistent in the SOP. However, in pharmaceutical industry, no company is consistent in SOP and in addition; Beximco Pharma shows inconsistency in reporting period. Overall, in terms of MOD, IVM, CS and AVM, all the companies, except Crown Cement (CC), show consistency in financial reporting because CC shows inconsistency in methods of depreciation. Of the 25 companies, only four companies are inconsistent in reporting period. Only five companies are consistent in the way of presentation, whereas 20 companies (80\% of our total sample size) are inconsistent in presenting their all relevant information in corporate financial reports. Overall, our findings report significant level of inconsistency in most of the steps in preparing annual reports through our study period. 


\begin{tabular}{|c|c|c|c|c|c|c|c|}
\hline Industry & Dimensions & 2013 & 2014 & $\begin{array}{l}\text { Year } \\
2015\end{array}$ & 2016 & 2017 & $\begin{array}{l}\text { Adoption of } \\
\text { principle-based }\end{array}$ \\
\hline \multirow[t]{5}{*}{ Cement } & Reporting period & $\sqrt{ }$ & $\sqrt{ }$ & $x$ & $\times$ & $\sqrt{ }$ & \\
\hline & Method of depreciation & $x$ & $x$ & $x$ & $x$ & $x$ & \\
\hline & Inventory valuation method & $x$ & $x$ & $\times$ & $x$ & $x$ & \\
\hline & Asset valuation method & $\sqrt{ }$ & $\sqrt{ }$ & $\sqrt{ }$ & $\sqrt{ }$ & $\sqrt{ }$ & \\
\hline & Step of presentation & $\times$ & $\times$ & $\times$ & $\times$ & $\times$ & 347 \\
\hline \multirow[t]{4}{*}{ Consumer products } & Reporting period & $\sqrt{ }$ & $\sqrt{ }$ & $\sqrt{ }$ & $\sqrt{ }$ & $\sqrt{ }$ & \\
\hline & Method of depreciation & $\stackrel{x}{x}$ & $\begin{array}{l}x \\
x\end{array}$ & $\begin{array}{r}x \\
x\end{array}$ & $\begin{array}{l}x \\
x\end{array}$ & $\begin{array}{l}x \\
x\end{array}$ & \\
\hline & $\begin{array}{l}\text { Inventory valuation method } \\
\text { Asset valuation method }\end{array}$ & $\sqrt[x]{\sqrt{ }}$ & $\sqrt[\times]{\sqrt{ }}$ & $\begin{array}{l}\times \\
\sqrt{ }\end{array}$ & $\sqrt[\times]{\sqrt{ }}$ & $\sqrt[\times]{\sqrt{ }}$ & \\
\hline & Step of presentation & $x$ & $\times$ & $\times$ &  & 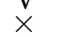 & \\
\hline \multirow[t]{6}{*}{ Engineering industry } & Reporting period & $\sqrt{ }$ & $\sqrt{ }$ & $\sqrt{ }$ & $x$ & $\sqrt{ }$ & \\
\hline & Method of depreciation & $\sqrt{ }$ & $\sqrt{ }$ & $\sqrt{ }$ & $\sqrt{ }$ & $\sqrt{ }$ & \\
\hline & Inventory valuation method & $\sqrt{ }$ & $\sqrt{ }$ & $\sqrt{ }$ & $\sqrt{ }$ & $\sqrt{ }$ & \\
\hline & Compliance status & $\times$ & $\times$ & $\times$ & $\times$ & $\times$ & \\
\hline & Asset valuation method & $\sqrt{ }$ & $\sqrt{ }$ & $\sqrt{ }$ & $\sqrt{ }$ & $\sqrt{ }$ & \\
\hline & Step of presentation & $\times$ & $\times$ & $\times$ & $\times$ & $\times$ & \\
\hline \multirow[t]{4}{*}{ Fuel and power industry } & Reporting period & $\sqrt{1}$ & $\sqrt{1}$ & $\sqrt{1}$ & $\sqrt{1}$ & $\sqrt{1}$ & \\
\hline & $\begin{array}{l}\text { Method of depreciation } \\
\text { Inventory valuation method }\end{array}$ & $\begin{array}{l}v \\
x\end{array}$ & $\begin{array}{l}v \\
x\end{array}$ & $\begin{array}{l}\sqrt{ } \\
\times\end{array}$ & $\begin{array}{l}\sqrt{ } \\
x\end{array}$ & $\begin{array}{l}v \\
\times\end{array}$ & \\
\hline & Asset valuation method & $\hat{\sqrt{ }}$ & $\hat{\sqrt{ }}$ & $\hat{\sqrt{ }}$ & $\hat{\sqrt{ }}$ & $\hat{\sqrt{ }}$ & \\
\hline & Step of presentation & $\times$ & $\times$ & $\times$ & $x$ & $\times$ & \\
\hline \multirow[t]{5}{*}{ Pharmaceutical } & Reporting period & $\sqrt{ }$ & $\sqrt{ }$ & $x$ & $\sqrt{ }$ & $\sqrt{ }$ & \\
\hline & Method of depreciation & $\times$ & $x$ & $x$ & $x$ & $\times$ & \\
\hline & Inventory valuation method & $x$ & $x$ & $x$ & $x$ & $x$ & Intercompany \\
\hline & Asset valuation method & $\times$ & $x$ & $\times$ & $x$ & $x$ & comparability of \\
\hline & Steps of presentation & $x$ & $x$ & $x$ & $x$ & $x$ & financial reports within \\
\hline \multicolumn{7}{|c|}{ Source(s): Based on function tables } & the same industry \\
\hline
\end{tabular}

\subsection{Intercompany comparability of financial performance}

Comparability of financial reports is one of the major qualitative characteristics in corporate financial reporting; especially for the current and potential investors. Although principle based IFRS provides flexibilities in the application of various depreciation and assets valuation methods, the application of same accounting methods for the same type of assets across the companies can ensure utmost intercompany comparability of financial performance within the same industry. It is observed that, other things remaining constant, differences in the application of accounting methods may show differences in corporate operating performance. Our thorough investigation on five function tables compiles the check list of intercompany comparability of financial reporting in summary Table 2.

4.2.1 Status of the reporting period. In 2013, 2014 and 2017, all the companies report their financial performance over 12-month period. In cement industry, one company (Confidence ) in 2015 and another one (Premier Cement) in 2016 report their financial performance semiannually. In pharmaceutical industry, Beximco Pharma reports its financial reports in 2015 over 18 months, in engineering industry, BSRM reports its financial reports in 2016 over 18 months. For rest of the periods, all the companies publish their financial reports annually. Our overall findings show very low level of disparity in reporting period.

4.2.2 Status of the application of method of depreciation. The application of methods of depreciation differs vastly among the companies. In cement industry, three companies use SL method, one company uses LFHB and another one uses RB method in 2013 but from 2014 two companies follow RB method, two companies follow SL method and one company follows 
AJAR

5,2

348

LFHB method of depreciation. In consumer goods industry, two companies use SL method and another three companies use RB method. But, all the companies in engineering industry and power and oil industry follow the RB and SL method, respectively. In pharmaceutical industry, all the companies follow SL method except Beximco which follows RB method. Although intercompany comparison in engineering and power and oil industry is possible in terms of method of depreciation, diversities in the application of methods of depreciation makes it problematic in another three industries.

4.2.3 Status of the application method of inventory valuation. The wide varieties in the application of IVMs have been found among the industries except engineering industry. In cement industry, three companies follow LC (least cost method) and two companies use weighted average cost method (WAC). In consumer goods industry, three companies use WAC method and two companies use LC method. In power and oil industry, one company uses LC method, three companies use WAC method and another one uses FIFO method. Two companies, in pharmaceutical industry, follow both LC and FIFO methods, two companies follow WAC method and the one company follows FIFO method. However, all the companies in engineering industry follow WAC method for inventory valuation. So, in terms of IVM, the intercompany comparability of operating performance becomes very complicated except engineering industry.

4.2.4 Status of assets presentation. All the companies, except ACME in pharmaceutical industry, use historical cost (HC) to report their assets on the balance sheet. HC is accordance with the GAAP and IFRS. Only ACME limited, out of 25 selected companies, uses the market value to report various assets on the balance sheet. So, in terms of assets presentation, our sampled companies show maximum similarities in presenting their various assets which are used as denominator to measure the operating performance of a particular firm.

4.2.5 Status of the steps of presentation. The steps of presentation (SOP) denote the various headings to disclose financial and nonfinancial items in annual reports to comply with full disclosure principle. The SOP reports very informative information required to analyze the operating performance of the companies. Our investigation on annual reports shows no uniformity in presentation sequences throughout the selected companies during our study period. Rather, very few companies are consistent in this regard and most of the companies are inconsistent presenting relevant information in the annual report. This causes wastage of much time of the stakeholders to collect and process relevant information making comparison among the companies.

Adoption of IFRS enhances the quality of financial reporting reducing information asymmetry (Houqe, 2018; Lourenço et al., 2015; Brochet et al., 2013) and has significant both positive (Isaboke and Chen, 2019; Barth et al., 2012; Bartov et al., 2005; Horton and Serafeim, 2006) and negative (Lin and Chen, 2005; Schiebel, 2007) impact on value relevance in the stock market. IFRS definitely enhances the overall comparability of accounting information (Brochet et al., 2013; Wang, 2011; Jermakowicz, 2004) although negative impact (Ahmed et al., 2013; Callao et al., 2007) is also found in literature review. In this study, it is clearly evidenced that adoption of IFRS could guarantee consistency in the application of accounting methods within the company and enhances intracompany comparability to a greater extent. However, the adoption of IFRS and compliance with it cannot guarantee the application of same accounting method for the same accounting issue across the companies within the same industry. If other things (revenues and expenses) remain same of the two companies, because of disparities in the application of accounting methods for deprecation, inventory valuation and so on can distort intercompany comparability of their operation performance. Consequently, IFRS could not ensure ultimate intercompany comparability within the same industry because of diversities in the application of various accounting methods among the companies. 


\section{Conclusion}

The existing literature discloses that adoption of and compliance with IFRS definitely enriches the quality of financial reporting, its value relevance in the stock markets and even enhances cross-country usages of financial information. However, the effectiveness of IFRS in a county to some extent depends on her enforcement capabilities by regulatory agencies (Lourenço et al., 2015). The contradictory outcomes are also found regarding the comparability of financial reports because of adoption of IFRS. If both IFRS and local reporting standard remain functional without synchronization between them, the overall comparability of financial reports become worsen (Callao et al., 2007). Our findings conclude that the adoption of IFRS in Bangladesh enhances the intracompany comparability to a greater extent but fails to achieve intercompany comparability of operating performance because of methodological diversities in financial reporting. We propose that the strict methodological specifications to neutralize managerial discretion relating to different accounting issues (such as asset valuation, assets presentation, reporting period and timeliness, depreciation, etc.) through local regulatory bodies as well as the proper adoption of and compliance with IFRS are essential to uphold supreme intercompany comparability of operating performance of various companies within the same industry and to make financial reports lucrative to its intended users. In this study, it is assumed that all the selected companies ensure compliance with IFRSs as a statutory requirement of ICAB. Moreover, although the quantitative analysis is absent in this study, the findings of this study is still crucial in accounting research to urge designing future studies to find out the ways of making financial reports more compatible for intercompany comparability of operating performance.

\section{Notes}

1. https://www.iasplus.com/en/jurisdictions/asia/bangladesh.

2. https://drive.google.com/file/d/1Rso5orPho4EWIv0Y6hZyCSDQQEsLiitW/view?usp=sharing.

\section{References}

Ahmed, A.S., Neel, M. and Wang, D. (2013), "Does mandatory adoption of IFRS improve accounting quality? Preliminary evidence", Contemporary Accounting Research, Vol. 30 No. 4, pp. 1344-1372, doi: 10.1111/j.1911-3846.2012.01193.

Amir, E. and Lev, B. (1996), "Value-relevance of nonfinancial information: the wireless communications industry", Journal of Accounting and Economics, Vol. 22 Nos 1-3, pp. 3-30, doi: 10.1016/S0165-4101(96)00430-2.

Armstrong, C.S., Barth, M.E., Jagolinzer, A.D. and Riedl, E.J. (2010), "Market reaction to the adoption of IFRS in Europe", The Accounting Review, Vol. 85 No. 1, pp. 31-61, doi: 10.2308/accr.2010.85.1.31.

Bamber, L.S., Jiang, J. and Wang, I.Y. (2010), "What's my style? The influence of top managers on voluntary corporate financial disclosure”, The Accounting Review, Vol. 85 No. 4, pp. 1131-1162, doi: 10.2308/accr.2010.85.4.1131.

Barth, M.E. (2013), “Global comparability in financial reporting: what, why, how, and when?”, China Journal of Accounting Studies, Vol. 1 No. 1, pp. 2-12.

Barth, M.E., Landsman, W.R., Lang, M. and Williams, C. (2012), "Are IFRS-based and US GAAP-based accounting amounts comparable?", Journal of Accounting and Economics, Vol. 54 No. 1, pp. 68-93, doi: 10.1016/j.jacceco.2012.03.001.

Bartov, E., Goldberg, S.R. and Kim, M. (2005), "Comparative value relevance among German, US and international accounting standards: a German stock market perspective", Journal of Accounting, Auditing and Finance, Vol. 20 No. 2, pp. 95-119.
Adoption of principle-based IFRS 
AJAR 5,2

Bassemir, M. and Novotny-Farkas, Z. (2018), "IFRS adoption, reporting incentives and financial reporting quality in private firms", Journal of Business Finance and Accounting, Vol. 45 Nos 7-8, pp. 759-796, doi: 10.1111/jbfa.12315.

Bhattacharya, N. (2001), "Investors' trade size and trading responses around earnings announcements: an empirical investigation", The Accounting Review, Vol. 76 No. 2, pp. 221-244.

Blankespoor, E. (2019), "The impact of information processing costs on firm disclosure choice: evidence from the XBRL mandate", Journal of Accounting Research, Vol. 57 No. 4, pp. 919-967, doi: 10.1111/1475-679X.12268.

Brochet, F., Jagolinzer, A.D. and Riedl, E.J. (2013), "Mandatory IFRS adoption and financial statement comparability”, Contemporary Accounting Research, Vol. 30 No. 4, pp. 1373-1400, doi: 10.1111/ 1911-3846.12002.

Brüggemann, U., Hitz, J.M. and Sellhorn, T. (2013), "Intended and unintended consequences of mandatory IFRS adoption: a review of extant evidence and suggestions for future research", European Accounting Review, Vol. 22 No. 1, pp. 1-37.

Callao, S., Jarne, J.I. and Laínez, J.A. (2007), "Adoption of IFRS in Spain: effect on the comparability and relevance of financial reporting", Journal of International Accounting, Auditing and Taxation, Vol. 16 No. 2, pp. 148-178.

Capkun, V., Collins, D. and Jeanjean, T. (2016), "The effect of IAS/IFRS adoption on earnings management (smoothing): a closer look at competing explanations", Journal of Accounting and Public Policy, Vol. 35 No. 4, pp. 352-394, doi: 10.1016/j.jaccpubpol.2016.04.002.

De Franco, G., Kothari, S.P. and Verdi, R.S. (2011), "The benefits of financial statement comparability", Journal of Accounting Research, Vol. 49 No. 4, pp. 895-931, doi: 10.1111/j.1475-679X.2011. 00415.x.

Di Piazza, S.A., McDonnell, D., Parrett, W.G., Rake, M.D., Samyn, F. and Turley, J.S. (2006), "Global capital markets and the global economy: a vision from the CEOs of the international audit networks", Paper Presented at the Global Public Policy Symposium: Investor Needs and Role of the Auditor - A Vision for the Future, Paris.

Donelson, D.C., McInnis, J.M. and Mergenthaler, R.D. (2012), "Rules-based accounting standards and litigation”, The Accounting Review, Vol. 87 No. 4, pp. 1247-1279, doi: 10.2308/accr-10274.

Durnev, A., Morck, R., Yeung, B. and Zarowin, P. (2003), "Does greater firm-specific return variation mean more or less informed stock pricing?", Journal of Accounting Research, Vol. 41 No. 5, pp. 797-836, doi: 10.1046/j.1475-679X.2003.00124.x.

Durnev, A., Morck, R. and Yeung, B. (2004), "Value-enhancing capital budgeting and firm-specific stock return variation", The Journal of Finance, Vol. 59 No. 1, pp. 65-105.

Ely, K. and Waymire, G. (1999), "Accounting standard-setting organizations and earnings relevance: longitudinal evidence from NYSE common stocks, 1927-93", Journal of Accounting Research, Vol. 37 No. 2, pp. 293-317.

Fang, X., Li, Y., Xin, B. and Zhang, W. (2016), "Financial statement comparability and debt contracting: evidence from the syndicated loan market", Accounting Horizons, Vol. 30 No. 2, pp. 277-303, doi: 10.2308/acch-51437.

Fawzi, L., Richard, F. and Oyelere Peter, B. (2001), "Public sector financial disclosure on the internet: a study of New Zealand local authorities”, Commerce Division, Discussion Paper No. 92, available at: http://dspace.lincoln.ac.nz/handle/10182/320.

Francis, J. and Schipper, K. (1999), "Have financial statements lost their relevance?", Journal of Accounting Research, Vol. 37 No. 2, pp. 319-352.

Ge, W., Matsumoto, D. and Zhang, J.L. (2011), "Do CFOs have style? An empirical investigation of the effect of individual CFOs on accounting practices", Contemporary Accounting Research, Vol. 28 No. 4, pp. 1141-1179, doi: 10.1111/j.1911-3846.2011.01097.x.

Hambrick, D.C. and Mason, P.A. (1984), "Upper echelons: the organization as a reflection of its top managers", Academy of Management Review, Vol. 9, pp. 193-206. 
Harris, M.S. and Muller, K.A. III (1999), "The market valuation of IAS vs US-GAAP accounting measures using form 20-F reconciliations", Journal of Accounting and Economics, Vol. 26 Nos 13, pp. 285-312.

Hope, O.K. (2003), "Disclosure practices, enforcement of accounting standards, and analysts' forecast accuracy: an international study", Journal of Accounting Research, Vol. 41 No. 2, pp. 235-272, doi: 10.1111/1475-679X.00102.

Horton, J. and Serafeim, G. (2006), "Market response to and the value relevance of reconciliation adjustments from UK GAAP to IFRS GAAP: first evidence from the UK", [consultado 5 May 2011].

Houqe, N. (2018), "A review of the current debate on the determinants and consequences of mandatory IFRS adoption", International Journal of Accounting and Information Management, Vol. 26 No. 3, pp. 413-442, doi: 10.1108/IJAIM-03-2017-0034.

Isaboke, C. and Chen, Y. (2019), "IFRS adoption, value relevance and conditional conservatism: evidence from China", International Journal of Accounting and Information Management, Vol. 27 No. 4, pp. 529-546, doi: 10.1108/IJAIM-09-2018-0101.

Jensen, M.C. and Meckling, W.H. (1976), "Theory of the firm: managerial behavior, agency costs and ownership structure", Journal of Financial Economics, Vol. 3 No. 4, pp. 305-360.

Jermakowicz, E.K. (2004), "Effects of adoption of international financial reporting standards in Belgium: the evidence from BEL-20 companies”, Accounting in Europe, Vol. 1 No. 1, pp. 51-70.

Kim, J.B., Liu, X. and Zheng, L. (2012), "The impact of mandatory IFRS adoption on audit fees: theory and evidence", The Accounting Review, Vol. 87 No. 6, pp. 2061-2094.

Kim, S., Kraft, P. and Ryan, S.G. (2013), "Financial statement comparability and credit risk", Review of Accounting Studies, Vol. 18 No. 3, pp. 783-823.

Li, S., Sougiannis, T. and Wang, S. (2017), "Mandatory IFRS adoption and the usefulness of accounting information in predicting future earnings and cash flows", SSRN, available at: https://ssrn.com/abstract $=2948775$.

Lin, Z.J. and Chen, F. (2005), "Value relevance of international accounting standards harmonization: evidence from A-and B-share markets in China", Journal of International Accounting, Auditing and Taxation, Vol. 14 No. 2, pp. 79-103.

Lin, S., Riccardi, W.N., Wang, C., Hopkins, P.E. and Kabureck, G. (2019), "Relative effects of IFRS adoption and IFRS convergence on financial statement comparability", Contemporary Accounting Research, Vol. 36 No. 2, pp. 588-628, doi: 10.1111/1911-3846.12475.

Lourenço, I.M.E.C., Branco, M.E.M.D.A. and Castelo, D. (2015), "Main consequences of IFRS adoption: analysis of existing literature and suggestions for further research", Revista Contabilidade and Finanças, Vol. 26 No. 68, pp. 126-139.

Malmendier, U. and Shanthikumar, D. (2007), “Are small investors naive about incentives?”, Journal of Financial Economics, Vol. 85 No. 2, pp. 457-489.

Nelson, M.W. (2003), "Behavioral evidence on the effects of principles-and rules-based standards", Accounting Horizons, Vol. 17 No. 1, pp. 91-104.

Nielsen, S. (2010), "Top management team internationalization and firm performance", Management International Review, Vol. 50 No. 2, pp. 185-206.

Nobes, C. and Parker, R. (2012), Comparative International Accounting (12:e uppl.), Ashford Colour Press Ltd, Gosport.

Ozkan, N., Singer, Z.V.I. and You, H. (2012), "Mandatory IFRS adoption and the contractual usefulness of accounting information in executive compensation", Journal of Accounting Research, Vol. 50 No. 4, pp. 1077-1107, doi: 10.1111/j.1475-679X.2012.00453.x.

Peña, H.F.P. and Franco, J.B. (2017), "Impact of IFRS on the quality of financial information in the United Kingdom and France: evidence from a new perspective”, Intangible Capital, Vol. 13 No. 4, pp. 850-878, doi: 10.3926/ic.939. 
AJAR 5,2

Peterson, K., Schmardebeck, R. and Wilks, T.J. (2015), "The earnings quality and information processing effects of accounting consistency", The Accounting Review, Vol. 90 No. 6, pp. 2483-2514.

Schiebel, A. (2007), "Value relevance of German GAAP and IFRS consolidated financial reporting: an empirical analysis on the Frankfurt stock exchange”, SSRN, 916103.

Schipper, K. (2003), "Principles-based accounting standards”, Accounting Horizons, Vol. 17 No. 1, pp. 61-72, doi: 10.2308/acch.2003.17.1.61.

Steccolini, I. (2004), "Is the annual report an accountability medium? An empirical investigation into Italian local governments”, Financial Accountability and Management, Vol. 20 No. 3, pp. 327-350.

Sunder, S. (2002), "Regulatory competition among accounting standards within and across international boundaries”, Journal of Accounting and Public Policy, Vol. 21 No. 3, pp. 219-234.

Sweeney, A.P. (1994), "Debt-covenant violations and managers' accounting responses”, Journal of Accounting and Economics, Vol. 17 No. 3, pp. 281-308.

Thorell, P. and Whittington, G. (1994), "The harmonization of accounting within the EU”, European Accounting Review, Vol. 3 No. 2, pp. 215-239.

Turki, H., Wali, S. and Boujelbene, Y. (2016), "The effect of IFRS mandatory adoption on the information asymmetry", Cogent Business and Management, Vol. 3 No. 1, p. 1209100.

Wang, C. (2011), “Accounting standards harmonization and financial statement comparability: evidence from transnational information transfer”, Working paper, The Wharton School, available at: http://papers.ssrn.com/sol3/papers.cfm?abstract_id=1754199.

Watts, R.L. and Zimmerman, J.L. (1986), Positive Accounting Theory, Prentice-Hall, Englewood Cliffs, NJ.

Yip, R.W. and Young, D. (2012), "Does mandatory IFRS adoption improve information comparability?”, The Accounting Review, Vol. 87 No. 5, pp. 1767-1789, doi: 10.2308/accr-50192.

Young, S. and Zeng, Y. (2015), “Accounting comparability and the accuracy of peer-based valuation models”, The Accounting Review, Vol. 90 No. 6, pp. 2571-2601, doi: 10.2308/accr-51053.

Zarova, M., Prochazka, D. and Roe, J. (2014), Financial Reporting and Management in Central and Eastern Europe, Nakladatelství Oeconomica, Praha.

\section{Corresponding author}

Protap Kumar Ghosh can be contacted at:pkghosh1982@gmail.com and protap.ba.2009@ku.ac.bd

For instructions on how to order reprints of this article, please visit our website:

www.emeraldgrouppublishing.com/licensing/reprints.htm

Or contact us for further details: permissions@emeraldinsight.com 